\title{
ANALYSES OF GENETIC VARIABILITY IN LENTINULA EDODES THROUGH MYCELIA RESPONSES TO DIFFERENT ABIOTIC CONDITIONS AND RAPD MOLECULAR MARKERS
}

\author{
Cristina Sayuri Makii ${ }^{12 *}$; Flavia França Teixeira² ${ }^{2}$ Edilson Paiva ${ }^{2}$; Luzia Doretto Paccola-Meirelles ${ }^{1}$ \\ 'Departamento de Biologia Geral, Centro de Ciências Biológicas, Universidade Estadual de Londrina, Londrina, PR, Brasil; \\ ${ }^{2}$ Núcleo de Biologia Aplicada, Centro Nacional de Pesquisa de Milho e Sorgo, EMBRAPA, Sete Lagoas, MG, Brasil.
}

Submitted: November 08, 2000; Returned to authors for corrections: March 12, 2001; Approved: June 2001

\begin{abstract}
The growth of thirty-four Lentinula edodes strains submitted to different mycelial cultivation conditions ( $\mathrm{pH}$ and temperature) was evaluated and strain variability was assessed by RAPD molecular markers. The growth at three $\mathrm{pH}$ values $(5,6$ and 7$)$ and four different temperatures $\left(16,25,28\right.$ and $\left.37^{\circ} \mathrm{C}\right)$ was measured using the in vitro mycelial development rate and water retention as parameters. Mycelial cultivation was successful at all $\mathrm{pH}$ tested, while the ideal temperature for mycelial cultivation ranged between 25 and $28^{\circ} \mathrm{C}$. The water content was lower in strains grown at $37^{\circ} \mathrm{C}$. Among 20 OPA primers (Operon Technologies, Inc.) used for the RAPD analyses, seventeen presented good polymorphism (OPA01 to OPA05, OPA07 to OPA14, OPA17 to OPA20). The clustering based on similarity coefficients allowed the separation of strain in two groups with different geographic origins.
\end{abstract}

Key words: edible mushroom, RAPD, mycelial growth

\section{INTRODUCTION}

The edible mushrooms have been used as a food alternative for more than 2000 years in Europe and Asia, where they were cultivated for consumption under primitive conditions (6). The shiitake [Lentinula edodes (Berk.) Pegl.] stands out among the species cultivated in the past and today it is produced on tree logs or sawdust (for example, eucalyptus, oak, mango, etc.). L. edodes is the third most important edible mushroom in the world in terms of total production $(3,4)$. Shiitake mushrooms develop as saprophytes on tree logs and form fruit bodies at low temperature $\left(15-20^{\circ} \mathrm{C}\right)$ and high humidity levels. These mushrooms grow in the wild in China, Japan, Korea, the Himalayas, the Philippines, Papua New Guinea and in the north of Thailand $(1,10)$. The scientifically proven therapeutic qualities of shiitake have raised the interest of researchers to isolate new active compounds from this mushroom. Although it is an age-old crop in Asian countries, its cultivation is recent in Brazil (1990s) and is mainly concentrated in the south and southeast areas of the country. In these regions, the shiitake produced is used for human consumption.
Shiitake cultivation can be divided into two stages: incubation and harvesting (8). During incubation, the mycelia secrete extra-cellular enzymes that act on substrate to form components that are then absorbed by the mycelia and used as source of raw material and energy for the metabolism. In the fructification or harvesting phase, the fungus begins to project the mushrooms in response to an external signal, which is generally a physical and/or a heat stress.

Little information is available on the behavior of $L$. edodes strains cultivated in tropical countries. This study was carried out on $34 \mathrm{~L}$. edodes strains to characterize their development response to different $\mathrm{pH}$ and temperature conditions, and to analyze their genetic variability using RAPD (Random Amplified Polymorphic DNA) molecular markers. This type of investigation provides essential information for shiitake strain breeding aiming high quality production. The present studies were focused on the $L$. edodes incubation phase, where the mycelia response to abiotic factors is directly related to the mycelial development rate. * Corresponding author. Mailing address: Embrapa Milho e Sorgo, Centro Nacional de Pesquisa de Milho e Sorgo, Núcleo de Biologia Aplicada, Rod.
MG-424, km. 65, Caixa Postal 151, 35701-970, Sete Lagoas, MG, Brasil. Fax: (+5531) 3779-1179. E-mail: csmaki@hotmail.com 


\section{MATERIALS AND METHODS}

\section{Strains}

34 dikaryotic $L$. edodes strains were used (Group A: 46-48; 50-52; 56-62; 66; 72; 74-76; 79; 102; Group B: Assaí; Ide-A, C; K1-4; Le1-5; Le10 and Curitiba). The strains in Group A came from the Instituto de Botânica (São Paulo/SP/Brazil) and those in group $\mathrm{B}$ belong to the L. edodes strains bank of the Laboratório de Genética de Fungos of the Universidade Estadual de Londrina (Londrina/PR/Brazil). The strains were maintained on Potato Dextrose Agar medium (PDA - Biobrás).

\section{Assessment of mycelial development in different $\mathrm{pH}$}

Each one of the $34 \mathrm{~L}$. edodes strains was transferred (three $10 \mathrm{~mm}$ discs of agar containing mycelia) to Erlenmeyer flasks containing $50 \mathrm{~mL}$ of potato broth at pHs 5, 6 and 7 and incubated at $25^{\circ} \mathrm{C}$ for 15 days. After this period the mycelia were filtered in a vacuum pump, washed in distilled water, weighed (moist weight $-\mathrm{MW}$ ) and dehydrated at $50^{\circ} \mathrm{C}$ to obtain the dry weight (DW). The mycelial water content (MWC) was calculated according to:

$\mathrm{MWC}=100-[(\mathrm{DW} / \mathrm{MW}) \times 100]$, where,

$\mathrm{MWC}=$ mycelial water content

$\mathrm{DW}=$ mycelial dry weight

$\mathrm{MW}=$ moist mycelial weight

Mycelial development was assessed from the dry weight of each individual strain.

\section{Mycelial development assessment at different temperatures}

Each one of the $34 \mathrm{~L}$. edodes strains were transferred (three $10 \mathrm{~mm}$ discs of agar containing mycelia) to Erlenmeyer flasks containing $50 \mathrm{~mL}$ of potato broth at $\mathrm{pH} 6.8$ and incubated at 16 , 25,28 and $37^{\circ} \mathrm{C}$ for 15 days. After this period the mycelia were filtered and washed in a vacuum pump. The mycelia were weighed and dehydrated at $50^{\circ} \mathrm{C}$ to obtain the dry weight (DW), and the mycelial water content (MWC) was calculated by the formula described above. A randomized complete block design with four replications was employed for both experiments: mycelial development in different $\mathrm{pH}$ and different temperatures. The mean comparison was done by the Tukey test at $5 \%$ probability.

\section{Nucleic acid extraction}

The L. edodes mycelia were cultivated in $50 \mathrm{~mL}$ of potato broth for 15 days at $25^{\circ} \mathrm{C}$, filtered in a vacuum pump, washed in autoclaved distilled water, weighed and squashed in liquid nitrogen. For each gram of squashed mycelia, $4 \mathrm{~mL}$ of extraction buffer pH 8.0 were added (Sigma Chemical Co.: 200mM Tris-HCl, 250mM NaCl, 25mM EDTA, 1\% SDS (p/v), $1 \mu \mathrm{L}$ of $\beta$-Mercaptoethanol for each milliliter of buffer, ultra pure water). The material was placed in a water bath $\left(65^{\circ} \mathrm{C}\right)$ for 15 minutes. It was then washed successively with phenol, phenol
+ chloroform (1:1) and chloroform + octanol (24:1) - Sigma Chemical Co. Each washing was followed by centrifugation at 4,000rpm for 15 minutes (IEC, Centra CL2) and the precipitate was discarded. The nucleic acids were precipitated with isopropanol $\left(-20^{\circ} \mathrm{C}\right.$, Sigma Chemical Co. $)$, inverted for 30 minutes, centrifuged at 8,000rpm for 5 minutes (Eppendorf Centrifuge 5402), three times washed with $70 \%$ ethanol (Labsynth) and resuspended in TE buffer (10mL Tris $1 \mathrm{M} \mathrm{pH} \mathrm{8,2mL} \mathrm{EDTA} 0.5 \mathrm{M}$ $\mathrm{pH} 8,988 \mathrm{~mL}$ ultra pure water). The tubes were kept under refrigeration $\left(4^{\circ} \mathrm{C}\right.$ overnight). For each $100 \mu \mathrm{L}$ of nucleic acid solution, $10 \mu \mathrm{L}$ of RNase $(10 \mathrm{mg} / \mathrm{mL}$, Boehringer Mannhein) was added and the mixture placed in a water bath for 10 minutes at $65^{\circ} \mathrm{C}$ and then washed with phenol + chloroform $(1: 1)$, centrifuged at 3,000rpm for 5 minutes. Chilled ethanol was then added to the supernatant for DNA re-precipitation. Aliquots of $5 \mu \mathrm{L}$ of DNA solution were placed in $0.8 \%$ agarose (Sigma Chemical Co.) gel for quantification by comparison with a quantifying standard (control). A spectrophotometer was used to determine the $\mathrm{A}_{260}$ / $\mathrm{A}_{280}$ relationship.

\section{RAPD reaction}

The kit A primers from Operon Technologies (OPA01 to OPA20) were used and their sequences are shown in Table 1. The thermocycler (Perkin Elmer Gene Amp 9.600) was used in the amplification reactions characterized by the following steps: $95^{\circ} \mathrm{C}(1$ minute $)+35 \times 94^{\circ} \mathrm{C}(10$ seconds $), 36^{\circ} \mathrm{C}(1$ minute $), 72^{\circ} \mathrm{C}$ ( 2 minutes $)+72^{\circ} \mathrm{C}(7$ minutes $)$. The negative control consists

Table 1. Specific base sequences and molecular weight of the Operon Technologies primers.

\begin{tabular}{ccc}
\hline Primer & Sequence $\left(\mathbf{5}^{\prime} \rightarrow \mathbf{3}\right.$ ') & Molecular Weight \\
\hline OPA 01 & CAGGCCCTTC & 2955 \\
OPA 02 & TGCCGAGCTG & 3035 \\
OPA 03 & AGTCAGCCAC & 2988 \\
OPA 04 & AATCGGGCTG & 3059 \\
OPA 05 & AGGGGTCTTG & 3090 \\
OPA 06 & GGTCCCTGAC & 2995 \\
OPA 07 & GAAACGGGTG & 3108 \\
OPA 08 & GTGACGTAGG & 3099 \\
OPA 09 & GGGTAACGCC & 3044 \\
OPA 10 & GTGATCGCAG & 3059 \\
OPA 11 & CAATCGCCGT & 2979 \\
OPA 12 & TCGGCGATAG & 3059 \\
OPA 13 & CAGCACCCAC & 2933 \\
OPA 14 & TCTGTGCTGG & 3041 \\
OPA 15 & TTCCGAACCC & 2939 \\
OPA 16 & AGCCAGCGAA & 3037 \\
OPA 17 & GACCGCTTGT & 3010 \\
OPA 18 & AGGTGACCGT & 3059 \\
OPA 19 & CAAACGTCGG & 3028 \\
OPA 20 & GTTGCGATCC & 3010 \\
\hline
\end{tabular}


of a sample containing only PCR buffer, primer, dNTPs, Taq polymerase and ultra pure water. The electrophoresis was performed in $1.2 \%$ agarose gels, that was stained in $10 \%$ ethidium bromide solution and bands were observed in an UV transilluminator (UVP). The data obtained by RAPD were analysed by the construction of a agreement matrix, by scoring the presence (1) or abscence ( 0 ) of a specific band on the gel for each one of the 17 primers tested. These analyses were carried out considering a total number of 110 polymorphic bands and the program used was Statistica 5.0 version (StatSoft, Inc.).

\section{RESULTS AND DISCUSSION}

\section{Assessment of $L$. edodes mycelial development in three pHs}

The influence of the culture medium $\mathrm{pH}$ was assessed on the L. edodes mycelial development and on the mycelial water content (MWC) of L. edodes strains cultivated under submerged culture at $25^{\circ} \mathrm{C}$ for 15 days. The strains developed well at the three tested $\mathrm{pHs}$ for fungus growth and, therefore, any of these pHs can be used for L. edodes cultivation in liquid medium. Fig. 1 shows the behavior of eight strains (the most contrasting of the 34 tested) in the test. Tukey test $(\mathrm{p} \leq 0.05)$ was used. No MWC differences were observed between the strains within the same $\mathrm{pH}$ and, also, no significant variation in any strain was detected in the analyses done in the three pHs (Fig. 2). Fungi develop in optimum $\mathrm{pH}$ ranges, which are related to enzymatic systems, essential vitamin entry in the cell, surface metabolic reactions and mineral capture (5). Some fungi, however, are able to adjust to the $\mathrm{pH}$ of the medium, optimizing it for their better development.

No significant differences were observed among the pHs tested for $L$. edodes development, probably because the mycelia

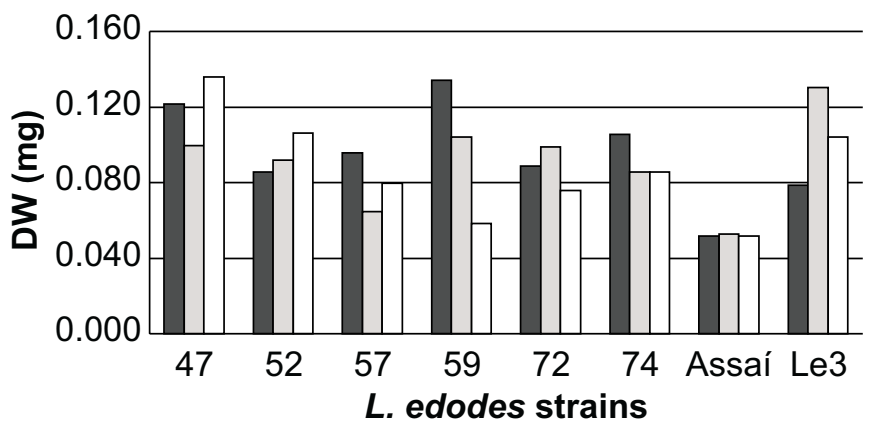

$\square \mathrm{pH} 5 \quad \square \mathrm{pH} 6 \quad \square \mathrm{pH} 7$

Figure 1. Mycelial Dry Weight (DW) of the eight most contrasting $L$. edodes strains cultivated in PDA medium at different $\mathrm{pHs}(5,6$ and 7$), 25^{\circ} \mathrm{C}$ for 15 days. The $\mathrm{pH}$ treatments for DW were not significantly different by the Tukey test at $5 \%$ probability. adapted to the medium $\mathrm{pH}$. Khan et al. (9) observed a $\mathrm{pH}$ reduction along the vegetative development of $L$. edodes obtaining $\mathrm{pH} 5$ as optimum for initial $L$. edodes mycelial growth, and a stabilization at $\mathrm{pH}$ close to 3.3, which would indicate the fungus passage from the first development phase (incubation phase) to the second (harvesting phase) $(7,8)$. The results showed here did not detect significant $\mathrm{pH}$ effect on the fungal development rate.

\section{Mycelial development assessment at different temperatures}

The temperatures of $25^{\circ} \mathrm{C}$ and $28^{\circ} \mathrm{C}$ were the most suitable for in vitro L. edodes growth. The temperature of $37^{\circ} \mathrm{C}$ was extremely unfavorable, while $16^{\circ} \mathrm{C}$ it just allowed the development of the strains $\mathrm{K} 2$ and Le3, indicating an interesting characteristic for cultivation of these strains in regions with a cooler climate $\left(16^{\circ} \mathrm{C}\right)$ (Fig. 3). No significant MWC difference was observed among the strains cultivated at the same temperatures (Fig. 4). In practice, the best strains for best quality seem to be those which require lower temperatures to reach the fructification phase $\left(8-16^{\circ} \mathrm{C}\right)$. However strains should be found for fructification at high temperatures to meet the needs of the mushroom market in countries with a tropical climate (2). As mycelial growth and fructification are different stages of the shiitake life cycle, the ideal temperature for one is not always the ideal for the other. Thus, the temperature effect on the two development stages should be considered, and strains that can grow under various temperatures should be selected to meet the grower needs.

\section{RAPD molecular markers analyses of the intraspecific variability}

Genetic variability for mushroom yield and quality is necessary for breeding higher yielding and better quality of the

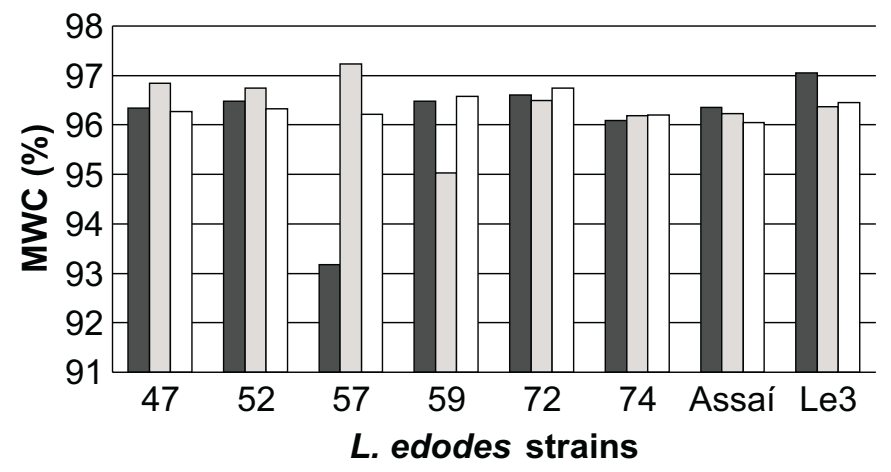

$$
\square \mathrm{pH} 5 \quad \square \mathrm{pH} 6 \quad \square \mathrm{pH} 7
$$

Figure 2. Mycelial Water Content (MWC) of the eight most contrasting $L$. edodes strains cultivated at three different $\mathrm{pHs}(5$, 6 and 7), $25^{\circ} \mathrm{C}$ for 15 days. The pHs treatments for MWC were not significantly different by the Tukey test at $5 \%$ probability. 
shiitake. Mushroom strains may differ for traits that can be recombined through crosses in conventional genetic breeding, or they can be submitted to protoplast fusion techniques or to transformation with cloned genes using recombinant DNA

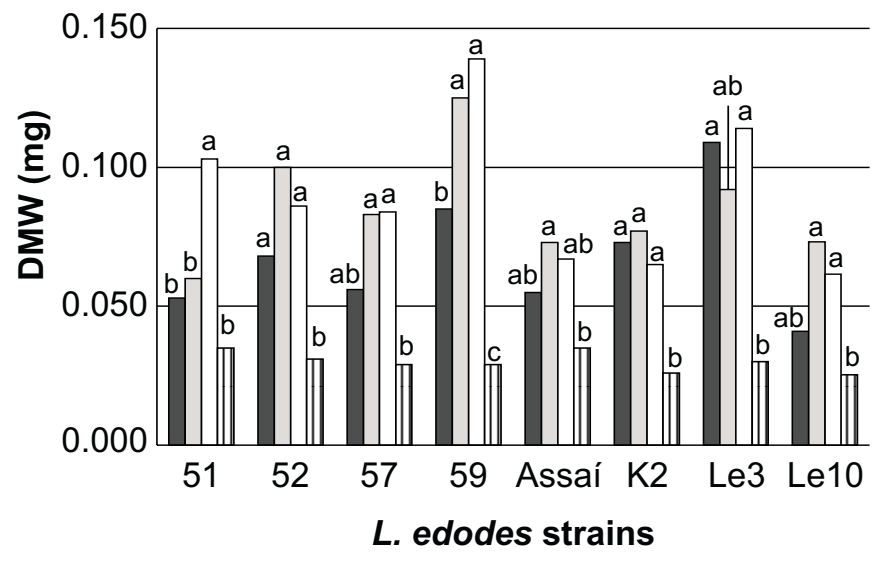

$16^{\circ} \mathrm{C} \quad \square 25^{\circ} \mathrm{C} \quad \square 28^{\circ} \mathrm{C} \quad$ 血 $37^{\circ} \mathrm{C}$

Figure 3. Mycelial dry weight (DW) of the eight most contrasting $L$. edodes strains cultivated at different incubation temperatures $\left(16,25,28,37^{\circ} \mathrm{C}\right)$ in PDA, $\mathrm{pH} 6.8$ for 15 days. Strains $\mathrm{K} 2$ and Le3 satisfactorily developed at $16^{\circ} \mathrm{C}$ indicating adaptation to reduced temperatures (winter strains). The temperatures treatments for DW were significantly different by the Tukey test at $5 \%$ probability. Means followed by the same letter did not differ statistically.

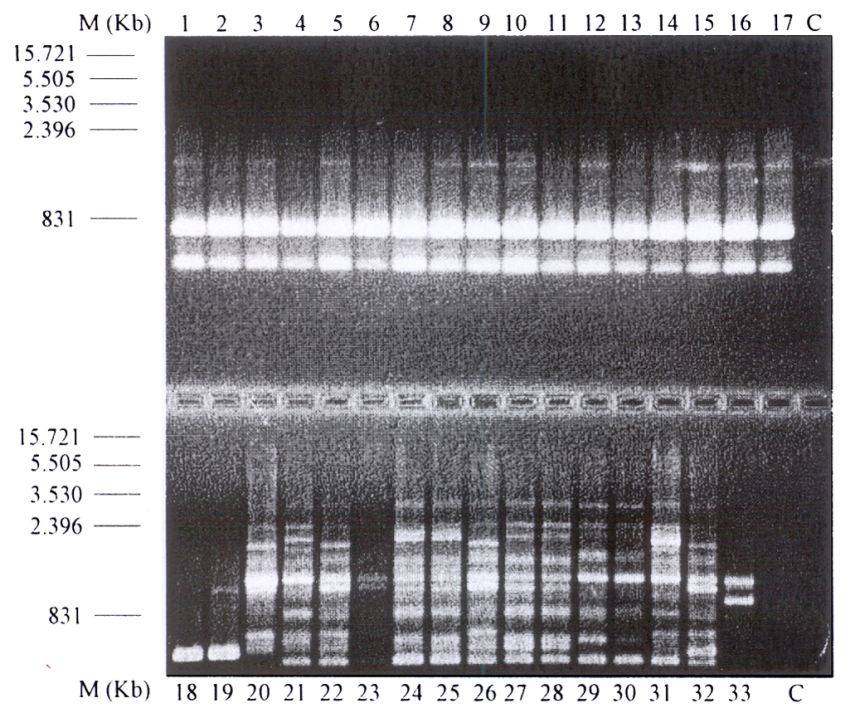

technology (2). Thus, the importance of assessing the genetic variability of the strains deposited in a germplasm bank. RAPD data (Fig. 5) shows that the technique can be used as a routine methodology for genotype identification (type) in L. edodes. Three primers (OPA06, OPA15 and OPA16) did not amplify the L. edodes DNA in the RAPD amplification reaction. This result

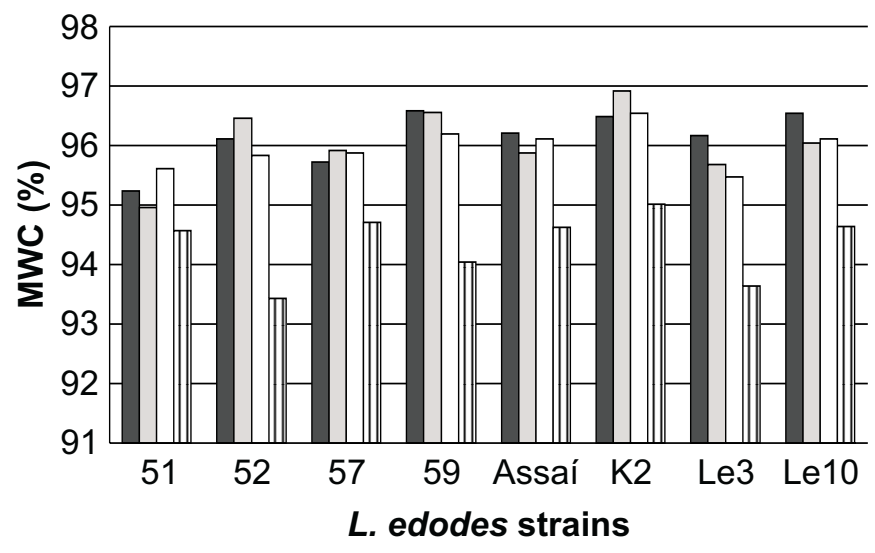

$16^{\circ} \mathrm{C} \quad \square 25^{\circ} \mathrm{C} \quad \square 28^{\circ} \mathrm{C} \quad$ 四 $37^{\circ} \mathrm{C}$

Figure 4. Mycelial Water Content (MWC) of the eight most contrasting $L$. edodes strains cultivated at four incubation temperatures $\left(16,25,28\right.$ and $\left.37^{\circ} \mathrm{C}\right)$ in PDA media, $\mathrm{pH} 6.8$ for 15 days. The temperatures treatments for MWC were not significantly different by the Tukey test at $5 \%$ probability.

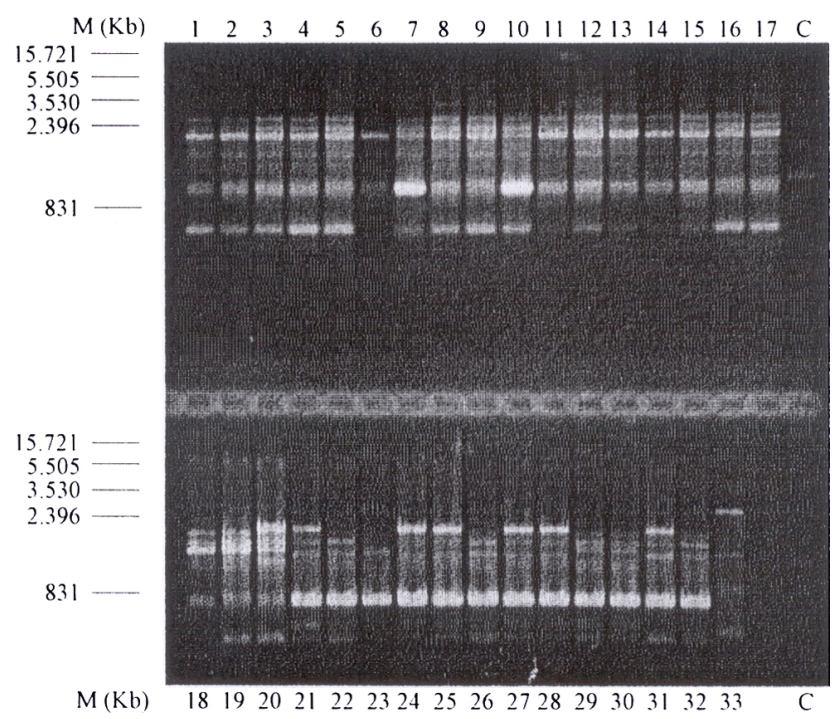

Figure 5. L. edodes amplification products in 1.2\% agarose gels, using the RAPD primers OPA08 (left) and OPA10 (right). Key: (M) Molecular weight; (C) Negative control and L. edodes strains: (1) 46; (2) 47; (3) 48; (4) 50; (5) 51; (6) 52; (7) 56; (8) 57; (9) 58; (10) 59; (11) 60; (12) 61;(13) 62; (14) 66; (15) 72; (16) 74; (17) 75; (18) 76; (19) 79; (20) 102; (21) Assaí, (22) Ide-A; (23) Ide-C; (24) K2; (25) K3; (26) K4; (27) Le1; (28) Le2; (29) Le3; (30) Le4; (31) Le5; (32) Le10; (33) Curitiba. 


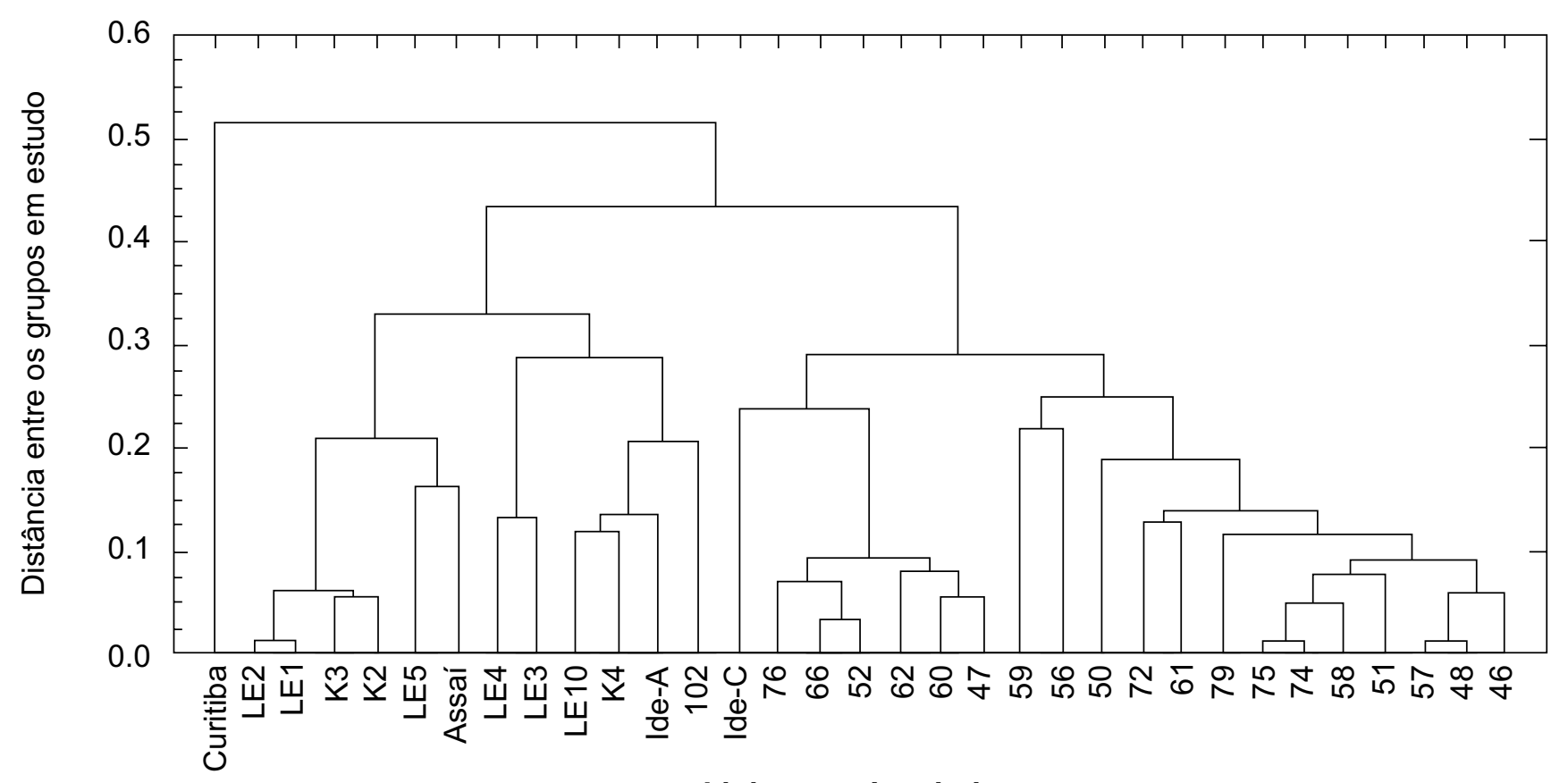

\section{Linhagens L. edodes.}

Figure 6. Dendogram from the cluster analysis and genetic distances among 34 L. edodes strains for polymorphism generated by the use of RAPD molecular markers.

is different from the study by Sunagawa (11) who found a large number of polymorphic bands with the OPA16 primer in a RAPD molecular marker analysis. It is suggested that the use of different strains in the two studies may be the cause of the difference in the results. The OPA04, OPA09 and OPA11 primers were also used by the same author, with good amplification of the L. edodes strains. Zhang and Molina (12) obtained good results with OPA01, OPA02, OPA04, OPA07, OPA08, OPA10 and OPA13. In this work, all the 17 primers tested showed consistency on bands intensity and amplification patterns reproducibility. The cluster analysis, based on the analysis of 17 primers (Fig. 6), indicated that the strains could be separated into two big groups: the first made of strains from the Instituto de Botânica de São Paulo and the second group of strains from the Strains Germplasm Bank at Universidade Estadual de Londrina. The Curitiba strain was completely isolated from the others. Although the Curitiba and other strains have presented some similar characteristics, it may possibly have been wrongly classified as belonging to the $L$. edodes species when in fact it does not. More specific and directed studies on this strain are needed to confirm this hypothesis. Some strains have a very similar RAPD pattern, as for example, strains Le1 and Le2, 74 and 75, 48 and 57. Producers in the São Paulo and Paraná regions have used these strains commercially for some years and they were probably obtained starting from a same origin (Japan and China).

The separation of the strains into two regional groups shows that each group may have had a common origin, and that the differences between strains in the same group result from recombination during the meiosis in the basidium. Monokaryotic or dikaryotic strains with interesting characteristics should be constantly sought by the mushroom breeder. The different alleles for traits of interest can be transferred among strains, either by traditional crosses or by genetic transformation, resulting in improved strains, which can be monitored by molecular methods, as previously described.

\section{ACKNOWLEDGMENTS}

The authors thank the financial support from CAPES and PRONEX, and the technical support from the research assistants Ideval Azarias de Souza (UEL), Miguel Francisco Assis dos Reis and Ubiraci Gomes de Paula Lana (EMBRAPA Milho e Sorgo). 


\section{RESUMO}

\section{Variabilidade genética em Lentinula edodes analisada por respostas de desenvolvimento do micélio a diferentes condições abióticas e por marcadores moleculares RAPD}

Analisou-se o comportamento de 34 linhagens de Lentinula edodes, quando submetidas a diferentes condições de cultivo micelial ( $\mathrm{pH}$ e temperatura), e a variabilidade das linhagens através de marcadores moleculares RAPD. A caracterização das linhagens foi realizada observando-se o comportamento de cada uma delas quando submetidas a três pHs $(5,6$ e 7) e quatro temperaturas diferentes $\left(16,25,28\right.$ e $\left.37^{\circ} \mathrm{C}\right)$, em função da taxa de desenvolvimento e da retenção de água pelo micélio in vitro. $\mathrm{O}$ cultivo micelial foi bem sucedido em todos os pHs utilizados. Já para o fator temperatura, foi estabelecido como faixas ideais para cultivo micelial, aquelas compreendidas entre 25 e $28^{\circ} \mathrm{C}$. O conteúdo hídrico foi menor nas linhagens cultivadas a $37^{\circ} \mathrm{C}$. O padrão de RAPD foi determinado e foram testados 20 primers OPA (Operon Technologies, Inc.), dos quais 17 forneceram boa fonte de polimorfismo (OPA01 a OPA05, OPA07 a OPA14, OPA17 a OPA20). O agrupamento das linhagens baseado nos coeficientes de similaridade permitiu a separação de dois grupos de procedências geográficas distintas.

Palavras-chave: cogumelos comestíveis, RAPD, crescimento micelial

\section{REFERENCES}

1. Campbell, A.C.; Slee, R.W. Commercial cultivation of shiitake in Taiwan and Japan. Mushroom J. Trop., 7:117-120, 1987.

2. Chang, S.T.; Kwan H.S.; Kang, Y.N. Collection, characterization, and utilization of germplasm of Lentinula edodes. Can. J. Bot., 73:S955-S961, 1995.

3. Chang, S.T.; Buswell, J.A.; Miles P.G. Genetics and Breeding of edible mushrooms. Gordon and Breach Science Publishers S.A. Amsterdam, 1991, 322p.

4. Chang, S.T. Mushrooms as human food. Bioscience, 30:399-401, 1980.

5. Cochrane, V.W. Physiology of Fungi. John Wiley, New York, 1958, $524 \mathrm{p}$.

6. Flegg, P.B.; WOOD, D.A. Growth and fruiting. In: Flegg, P.B.; Spencer, D.M.; Wood, D.A (eds). The Biology and Technology of the Cultivated Mushroom. Dorchester, Grã-Bretanha, 1985, p.141-178.

7. Jablonsky, I. Changes in biochemical and physiological activities of substrates colonized by fyngi P. ostreatus, L. edodes and A. aegerita. Proceedings of the Eleventh International Scientific Congress on the Cultivation of Edible Fungi, Australia, 1981, p. 659-673.

8. Kalberer, P.P. An investigation of the incubation phase of a shiitake (Lentinus edodes) culture. In: Elliot, T. J. (ed). Science and Cultivation of Edible Fungi. Roterdam, 1995, p.375-383.

9. Khan, S.M.; Mirza, J.H.; Khan, M.A. Studies on shiitake mushroom (Lentinula edodes (Berk.) Pegler). In: Maher (ed). Science and Cultivation of Edible Fungi. Roterdam, 1991.

10. Mori, K.; Fukai, S.; Zennyoji, A. Hybridization of shiitake (Lentinus edodes) between cultivated strains of Japan and wild strains grown in Taiwan and New Guinea. Mushroom Sci., 9:391-403, 1974.

11. Sunagawa, M.; Neda, H.; Miyazaki, K. Identification of Lentinula edodes by random amplified polymorphic DNA (RAPD) markers. In: Elliot, T.J. (coord.) Science and Cultivation of Edible Fungi, Roterdam, 1995, p.141-145.

12. Zhang, Y.; Molina, F.I. Strain typing of Lentinula edodes by random amplified polymorphic DNA assay. FEMS Microbiol. Lett., 131:1720, 1995. 